Original Research Paper

\title{
Saudi Women's Rights in Civil Public Service System
}

\author{
Dr. Haifa Abdul Rahman Saleh Bin Shalhoub, Dr. Huda Ahmed Al-Khayyal, \\ Dr. Hassa Abdulrahman Al Sanndh and Dr. Hind Fayia Al-Shahrani
}

Department of Social Planning, Princess Nora Bint Abdulrahman University, Riyadh, Saudi Arabia

\author{
Article history \\ Received: 16-01-2017 \\ Revised: $29-09-2017$ \\ Accepted: 13-11-2017 \\ Corresponding Author: \\ Haifa Abdul Rahman Saleh Bin \\ Shalhoub \\ Department of Social Planning, \\ Princess Nora Bint \\ Abdulrahman University, \\ Riyadh, Saudi Arabia \\ Tel: 00966505411421 \\ Email: dr.haifaa2014@gmail.com
}

\begin{abstract}
This paper aims at understanding the reality of Saudi women's rights in Civil Public service system. In doing so, it aims to examine the planning indicators aimed at increasing awareness about Saudi women's rights. In order to achieve the objectives of the study, the research uses statistical measures-Mean, Standard Deviation and Independent Sample Ttest alongside other scientific test techniques such as One Way ANOVA. A survey was conducted amongst 338 faculty members of five different universities and 384 other university staff. The data was analyzed using SPSS software, which was then verified to test the indications of reliability and validity. The findings indicate increasing level of awareness amongst Saudi women regarding their rights in civil public service system.
\end{abstract}

Keywords: Saudi Women, Women's Rights, Social Planning Indicators, Civil Public Service

\section{Introduction}

It is well established that the Saudi society is a religiously and socially conservative one in which the family remains at the crux of the unit. This is because the Islamic law foregrounds the integrity of the family unit through its regulations on marriage, divorce, child custody and inheritance (Natana, 2009). Moreover, the government of the Kingdom of Saudi Arabia (KSA), as per the Islamic law champions imposition of sex segregation in its totality. Although this policy, when assessed in its face value, does not look to be a discriminatory one since the policy is intended to target both women and men, in reality, it restraints Saudi women from accessing significant everyday public life practices (Safaa, 2014).

Scholars argue that Saudi women's inequalities are deeply embedded within the traditional norms and values of the society and are institutionalized (Safaa, 2014). It should be noted however, that in Saudi society, women's issues are very often wrongly linked to Islamic teachings. Through individual actions, it is very difficult to dislodge these institutionalized gendered inequalities. In 2004, 13 social protection committees were established by the Higher National Committee specialized in women's affairs. Therefore, in 2008, the KSA was in the process of drafting a new legislation to implement women's rights in addition to the State party plans, which aimed to compile, in writing, the personal status provisions under Sharia legislation (CEDAW, 2008).
Nonetheless, women's rights have been improving modestly in KSA. Women are now allowed to study law, can have their own identity cards, are allowed to check into hotels alone and even are themselves registered to start up their own business, where they are not required to prove that they have employed a male manager. Above all, King Salman issues a decree to allow women to drive (Smith-Spark et al., 2017). However, despite these positive improvements, the overall degree of freedom of Saudi women remains one of the most restricted in the world (Sanja, 2009).

In the light of these backdrops, this article aims at determining the reality of Saudi women's rights in civil public service system. The findings of this research underpinning the planning indicators are reckoned to increase awareness amongst Saudi women about their rights in civil public service system.

\section{Civil Public Service System at KSA}

As stated above, in recent years, Saudi women's status have been improving with increased access to some forms of economic rights, such as establishment of companies and charitable institutions. This is of course the consequence of a Royal decree, which was issued to reform the Civil Service Commission 9 for a period of three years. On the expiry of its term on August 16, 2004, it promulgated the Civil Service Regulations, which defined the public functions, officials, their functions, duties, allowances, indemnities, awards, compensation, termination of service and general and transitory provisions (UN, 2004). 
However, these new civil service duties and disciplinary rules were framed in such a way that they are compatible with the social values and Islamic heritages. Though the Saudi government has enacted civil service and disciplinary regulations influenced by the Egyptian experience, it has also maintained that the civil service enactments must find their justifications in Islamic law and its heritage (Abd El-Mahdi, 1992).

\section{The Evolution of Civil Service System at KSA}

'Abd al-'Aziz bin 'Abd al-Rahman Al Saud established the KSA in 1932 by marking the culmination of several decades of successful military and political efforts. Currently, KSA is a home to a population of more than 28 million, $82 \%$ of whom live in urban areas. KSA is well known for its influence, which radiates not only across its surrounding regions but also throughout the world in the form of investment of capital, media, foreign aid, the championing of Muslim causes and the conduct of diplomacy (MEI, 2016).

Because of the stringent rule of the land, the UN Human Rights Commission criticized KSA rigorously. However, in 2004, the KSA approved of the inception of National Society for Human Rights (NSHR), where the KSA recruited government employees aimed at monitoring implementation of human rights. Earlier, during the period 1996-2000, Saudi Arabia acquiesced into four UN human rights conventions. Nonetheless, NSHR's activities are estimated to be limited and there are doubts over its independence and impartiality. It is to be noted here that UN's Universal Declaration of Human Rights was launched in 1948; Saudi Arabia was one of the eight countries that had failed to adopt it. KSA continues to resist openly to the declaration. In counter to the continued human rights record criticism, the KSA responses by pinpointing the country's special Islamic character and justifying this character via a different social and political hierarchy (Wikipedia, 2016).

In December 2015, Saudi women were not only allowed to cast their votes but also stand as candidates in Municipal elections. Moreover, amidst much social restrictions, 20 women candidates managed to win out of 2,100 Municipal Council seats. This is however just the beginning. Earlier, though women were allowed to vote in some limited elections and were allowed to stand in the elections of the Chamber of Commerce of Jeddah and Dammam. In the end of 2004, the KSA held its national Municipal elections, where women were disallowed to participate because the infrastructure for women's participation was not complete then. Surprisingly, although UNDP remained as an adviser to the High Commission for the 2004 Municipal elections, however, it did not criticize KSA's decisions on debarring women from elections rather considered the country's step as an advancement to women's improvement in status, although, in this election only $10 \%$ of the population came out to cast their votes.

\section{The Reality of Saudi Women's Rights in Civil Public Service System}

\section{The Economic System and Saudi Women's status}

In 2016, with an estimated 1.2\% real GDP growth rate and $\$ 637.8$ billion GDP as per 2015 estimate, Saudi Arabia has a robust economy "but remains largely dependent on the production and exportation of oil. Saudi Arabia produces more oil and natural gas liquids than any other country in the world. The Saudi Arabia Oil Company (Saudi Aramco), which was fully nationalized in 1988, controls this vitally important resource" (FRD, 2006).

It remains well documented that Prophet Muhammad's first wife, Khadija, was a businessperson. Hence, it is well argued that in Islamic tradition, women bear their right to engage in commercial and business transactions. Saudi women increasingly cite the example of Khadija while making their demands for increased job opportunities and training programs. In the light of this argument, perhaps, the Chambers of Commerce and Industry in different cities of the country have been supporting women, who sought to start their own businesses, acquire training and search jobs. In addition, the Chambers of Commerce and Industry have allowed women to be elected to the Boards of Directors of the Chambers, thereby, allowing the women the opportunity to both participate in and contest elections. It is anticipated that the practical experience in a field, although minuscule but considered legitimate in Islamism could perhaps transfer into other areas in the future (Natana, 2009).

Nonetheless, the economy of KSA, which is one of the least understood one, has doubled in size during the decade 2003-2013 mainly due to its protracted oil boom. Simultaneously, significant modernization not only brought in prosperity but also transformed the Saudi society. During the decade, the growing modern economy through its market-based approach created 1.7 million jobs, invested $\$ 450$ billion in health, education and infrastructure and improved the household incomes for the Saudi nationals. Indeed, during this decade, the household income grew by about $75 \%$ and that too after inflation adjustment, which in turn escalated the living standards, improved quality of life. All these improvement might help the KSA attain further ambitious goals (Gassan et al., 2015).

However, women's role continues to remain limited in the Saudi labor force. Nearly, half of the total workforce is comprised of foreign workers, from countries mainly from India, Pakistan and Bangladesh. These workers are more or less unskilled "and are paid far less than Saudi nationals; their average monthly wages of $\$ 400$ are less than one-third the average monthly wage for Saudi nationals in the private sector and one-sixth the average for Saudi public-sector employees" (Gassan et al., 2015). 
In 1980 , the KSA took steps to open women's banks aimed at helping its women deposit money without being in contact with men. These types of women's banks are for women and run exclusively by women employees except for the guards, who are posted at the door to watch out for that, no men gain access to these banks even by mistakes. However, currently, Saudi women are more visible in developing professional careersdoctors, teachers, lawyers and even business persons, etc.https://en.wikipedia.org/wiki/Women $\% 27 \mathrm{~s}$ rights in Saudi_Arabia\#Business and property

\section{The Educational System and Saudi Women's Status}

Education within the KSA remains closely connected to Islamic teachings. Therefore, one can easily assume that all forms of curricula conforms largely to not only Islamic laws and the Quran, but also acknowledges traditional gender roles that tend to limit female educational opportunities. Despite this, female's education has increased dramatically from $25 \%$ of all students in 1970 to $47.5 \%$ in 2001 . In addition, the latest 2015 estimated statistics unravels that while $91.1 \%$ females are literate, the male literacy stands at $97 \%$. Nonetheless, instructions in classrooms remain rigorously segregated. It is worth noting here that despite progress in women's education, they "can only attend six of the nation's eight universities and they are prohibited from studying certain subjects (FRD, 2006).

Because of its unique blend of religion and culture, it poses difficulties for the KSA to develop women's education in many arenas, which are largely considered as male subjects and women continue to face barriers (Yahya, 2015).

In its 2009 report, the Ministry of Economy and Planning on the achievement of the Millennium Development Goals in Saudi Arabia states that: "[e]ducation is a main pillar of economic and social development and the most important factor of its sustainability. If the ultimate goal of development in a developed society is improving human welfare, then this cannot be attained without educated, productive citizens and individual commitment to human values and ideals" (Annalisa, 2014).

In Saudi society, women' issues and the embedded gender inequalities in its educational system are institutionalised and it is not easy to delink it through individual actions. "The rational for a need to focus on women's achievements in higher education is considered a key social development indicator measuring women's statues and conditions in any country" (Rashti, 2004).

Overall, at all levels, in Saudi Arabia, the public education system is sex-segregated and generally, females and males are allowed to attend different schools. Moreover, men are disallowed from working or teaching at girls' schools. Similarly, women are forbidden from working at boys' schools. It should be noted here that Princess Nora bint Abdul Rahman University is the world's largest women-only university where large number of Saudi women seek higher education. However, religious ideologies about gender roles and the entrenched belief that education is more important and pertinent to men than women has ramified in lesser opportunities for women's education, where traditionally women faced restrictions in pursuing pharmacy, architecture, engineering and even legal courses. (https://en.wikipedia.org/wiki/Women\%27s_rights_in_S audi_Arabia\#Business_and property).

\section{The Political System and Saudi Women's Status}

As stated above, in terms of civil rights, women were allowed to cast their votes and stand for Municipal elections only in December 2015. In this election however, only $0.009 \%$ women candidates managed to win council seats. Hence, the continued exclusion of women in political life remains one of the most heated debates not only in contemporary Saudi society but also worldwide. "In 1980, there were more female graduates in the humanities than male. University women could study most of the same subjects as their male counterparts except those, which might lead to their mixing with men" (Amani, 2005).

\section{The Health System for Saudi Women Status}

In 1970, with the launch of its first five-year development plan, health benefits for Saudi citizens augmented tremendously. As discussed above, $\$ 450$ billion in health, education and infrastructure were invested during the period 2003-2013 to build and operate hospitals throughout the country. Currently, as per the Saudi government, every citizen is a beneficiary to its unlimited and free medical care. Scholars argue that Saudi women in general suffer in their well-being when compared to their male counterparts. They go on to argue that women's well-being are affected by poverty, lower education and less pay than men, violence, male dominance and lack of social equity and health care accessibility (Al Joharah et al., 2014).

\section{Methodology}

This is a triangulated two-shot study conducted to examine Saudi women's rights in civil public service system using two questionnaires-the first, within the faculty members of the five universities of KSA. The second questionnaire was conducted amongst the staff in these five universities. A detailed demographic sheet was used to collect information from the faculty members and the staff, (supplementary 1). Out of the total faculty members and staff, simple sample technique was used to conduct the survey amongst 338 faculty members out of 
a total of 2648 faculty members and 384 staff out of 20689. Mean, Standard Deviation and Independent Sample T-test were used along with other scientific test techniques-One Way ANOVA. The questionnaire contained three sections-Section 1 tried to collect the demographic information of the respondents. Section 2 aimed at retrieving information regarding awareness of rights, factors affecting women's rights in civil public service system, the reality of women's rights in civil public service system and lack of aspects in civil public service system. And Section 3 comprised of questions regarding modification of civil public service system with respect to Saudi women's employment. It should be noted here that for the one way ANOVA test, the indicators were divided into five axes, which are further sub-divided into four subdivisions-age, type of qualification, type of job and experience of the job of the respondents. The details are as follows:

- Awareness of rights (scientific qualification, job and experience of the job)

- Factors affecting women's rights awareness in civil public service system (age, scientific qualification, job and experience of the job)

- The axis of the reality of women's rights in civil public service system (scientific qualification, and the job)
- The axis of lack of aspects in civil public service system (age, scientific qualification, job and experience of the job)

- The axis of modification of civil public service system in Saudi women's employment (age, scientific qualification, job and experience of the job)

\section{Findings}

The sampling size, response rate and demographic data analysis are provided in Fig. 1 and Tables 1, 2 and 3.

\section{Results and Discussion}

Figure 1 presents the breakdown of sample, which has already been discussed in detail in the methodology section. The value of Cronbach's alpha test (here, 0.8512 ) is used to check the reliability of the instruments as shown in Table 1 and is reckoned very good. Table 2 illustrates the detail results of the independent sample t-test to gain an understanding of Saudi women's rights in Civil Public Service System.

Table 1: Reliability analysis- scale (alpha)

\begin{tabular}{ll}
\hline Reliability coefficients & \\
\hline No. of cases $=15$ & No. of Items $=63$ \\
Alpha $=0.8512$ & \\
\hline
\end{tabular}

Table 2: The results of Independent Sample t-test of sample responses on the axis priority focus of the work location (Schools and Universities)

\begin{tabular}{|c|c|c|c|}
\hline The axis & The work location & T. value & Significance \\
\hline Awareness of rights & $\begin{array}{l}\text { Schools } \\
\text { Universities }\end{array}$ & $4.136-$ & $0.000 * *$ \\
\hline $\begin{array}{l}\text { Factors affecting women's rights } \\
\text { awareness of in Civil Public service system }\end{array}$ & $\begin{array}{l}\text { Schools } \\
\text { Universities }\end{array}$ & 5.514 & $0.000 * *$ \\
\hline $\begin{array}{l}\text { The reality of women's rights in } \\
\text { Civil Public service system }\end{array}$ & $\begin{array}{l}\text { Schools } \\
\text { Universities }\end{array}$ & $4.203-$ & $0.000 * *$ \\
\hline Lack of aspects in Civil Public service system & $\begin{array}{l}\text { Schools } \\
\text { Universities }\end{array}$ & 8.979 & $0.000 * *$ \\
\hline $\begin{array}{l}\text { Modification of civil public service } \\
\text { system in Saudi women's employment }\end{array}$ & $\begin{array}{l}\text { Schools } \\
\text { Universities }\end{array}$ & 9.267 & $0.000 * *$ \\
\hline
\end{tabular}

Table 3: The results Independent Sample One Way ANOVA of sample responses on the axis priority focus of some basic data

\begin{tabular}{|c|c|c|c|}
\hline The axis & Some basic data & F. value & Significance \\
\hline \multirow[t]{4}{*}{ Awareness of rights } & The Age & 2.572 & 0.053 \\
\hline & Scientific Qualification & 8.157 & $0.000 * *$ \\
\hline & The Job & 8.664 & $0.000 * *$ \\
\hline & Experience of the job & 9.285 & $0.000 * *$ \\
\hline \multirow{4}{*}{$\begin{array}{l}\text { Factors affecting women's rights } \\
\text { awareness of in Civil Public service system }\end{array}$} & The Age & 6.267 & $0.000 * *$ \\
\hline & Scientific Qualification & 5.064 & $0.000 * *$ \\
\hline & The Job & 12.298 & $0.000 * *$ \\
\hline & Experience of the job & 8.650 & $0.000 * *$ \\
\hline The reality of women's rights in & The Age & 3.210 & $0.022 *$ \\
\hline \multirow[t]{3}{*}{ Civil Public service system } & Scientific Qualification & 7.185 & $0.000 * *$ \\
\hline & The Job & 9.143 & $0.000 * *$ \\
\hline & Experience of the job & 2.623 & 0.073 \\
\hline \multirow[t]{4}{*}{ Lack of aspects in Civil Public service system } & The Age & 16.700 & $0.000 * *$ \\
\hline & Scientific Qualification & 12.015 & $0.000 * *$ \\
\hline & The Job & 53.586 & $0.000 * *$ \\
\hline & Experience of the job & 28.603 & $0.000 * *$ \\
\hline Modification of Civil Public service system in & The Age & 7.667 & $0.000 * *$ \\
\hline \multirow[t]{3}{*}{ Saudi women's employment } & Scientific Qualification & 12.636 & $0.000 * *$ \\
\hline & The Job & 39.246 & $0.000 * *$ \\
\hline & Experience of the job & 10.284 & $0.000 * *$ \\
\hline
\end{tabular}




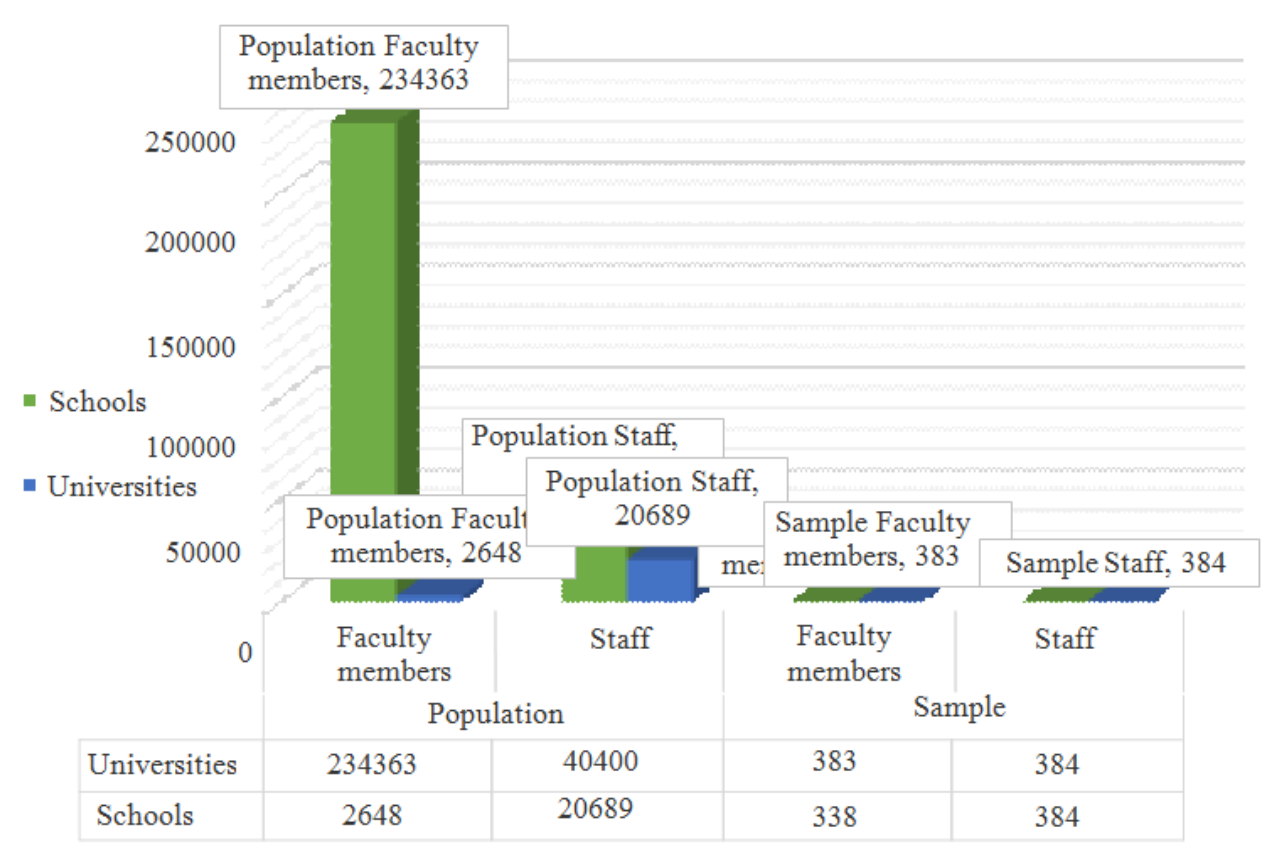

Fig. 1: Population, Sample and Response Analysis

The t. value varies amongst the indicators - the findings signal that despite improvement in Saudi women's rights in civil public service system, more needs to be done to redress women's rights in the same. Table 3 describes the results of the independent sample using One Way ANOVA wherein the differences of statistical significance are illustrated in-depth. That is, while F.value of each axis is calculated; in majority of the axes and its sub-indicators, there are no differences in statistical significance and the value stands at 0 , except for three subindicators, where the values are respectively 0.053 (for age indicator in the axis-awareness of rights), 0.022 (for age indicator in the axis-the reality of women's rights in the civil public service system) and 0.073 (for the job experience indicator-the reality of women's rights in the civil public service system).

\section{Conclusion}

This study aimed at determining the following:

- First, identify and analyze the reality of rights granted to Saudi women in civil public service system

- Second, identify deficiencies in the system and the degree of awareness of women's rights

- Third, identify the factors affecting awareness

- Fourth, determine the relationship between the level of women's awareness of their rights in the civil service system and the reality of this system

- Sixth, try at reaching the mechanisms aimed at increasing awareness with respect to Saudi women's rights in the civil public service system. Some of the recommendations include:

Firstly, development of awareness regarding Saudi women's rights in civil public service system, such as:

a) Determine the Ministry of Civil Public service system procedures for raising women's rights awareness, through-I. Write a formula contract between the employee and the point of employment prior to appointment so that the contract document contains a comprehensive explanation of their rights and duties, II. Formula advertising messages must be posted across a variety of tools-visible, audible and legible under direct supervision of the ministry, III. Provide women's employment system documentation points to look at and comeback, IV. Prepare periodic meetings and seminars on women's rights and awareness

- Second, prepare studies on ways to improve women's rights awareness in Saudi Arabia service system

b) Determine the Ministry of Civil Public service system procedures for measuring the level of women's rights awareness, through the following-I. centralized network communication between the ministry and the government agencies that employ women, II. conduct descriptive surveys to identify the extent of knowledge on women's rights and III. conduct 
continuously evaluation measures to determine the level of women's rights awareness

Third, development of the civil service system at KSA to meet women's rights, such as:

a) establishment of a special independent system for women employees according to the nature of women and Islamic legislation

b) employment of women in the absolute powers in the departments of top jobs

c) setting up a network of communication between the rehabilitation and training of women's views and their employment

d) reduce the current retirement age for women working, appropriate to the age allowed to enter new numbers of women into the labor market

\section{Acknowledgements}

This work was supported by the Promising Research center in Social Research and Women's Studies under Grant [number Funding; M.B .10].

Therefore, we are very grateful to the Promising Research center in Social Research and Women's Studies at Princes Nourah Bint Abdualrahman University, KSA.

\section{Author's Contributions}

Dr. Haifa Abdul Rahman Saleh Bin Shalhoub: Coordinated the data-analysis and contributed to the writing of the manuscript.

Dr. Huda Ahmed Al-Khayyal: Coordinated the mouse work.

Dr. Hassa Abdulrahman Al Sanndh: Designed the research plan and organized the study.

Dr. Hind Fayia Al-Shahrani: Designed the research plan and organized the study.

\section{Ethics}

This article is original and contains unpublished material. The corresponding author confirms that all of the other authors have read and approved the manuscript and there are no ethical issues involved.

\section{References}

Abd El-Mahdi, M., 1992. An analysis of the civil service disciplinary system of Saudi Arabia and Kuwait: An Islamic perspective and a comparative overview. Penn State International Law Review.

Al Joharah, M.A., R.S. Amna, H.Q. Riaz, A.F. Mona and A.A. Maha et al., 2014. Women Health in Saudi Arabia: A review of non-communicable diseases and their risk factors. Pak. J. Med. Sci., 30: 422-431.
Amani, H., 2005. Women and education in Saudi Arabia: Challenges and achievements. Int. Education J., 6: 42-64. Annalisa, P., 2014. The new Saudi educational renaissance: In between the capacity to aspire- and the -capacity to remember. Higher Education Studies.

CEDAW, 2008. Concluding comments of the Committee on the Elimination of Discrimination against Women (Report No.08-29880). United Nations, 14 Session, Committee on the Elimination of Discrimination against Women.

FRD, 2006. Country Profile: Saudi Arabia: Library of Congress.

Gassan, J., J. Tom and J. Hassan, 2015. Saudi Aribia beyond Oil: The Investment and Productivity Transformation. McKinsey Global Institute.

https://en.wikipedia.org/wiki/Women $\% 27 \mathrm{~s}$ rights_in_Sa udi Arabia\#Business and property

MEI, 2016. The Kingdom of Saudi Arabia, 1979-2009: Evolution of a Pivotal State: Viewpoints Special Edition. Washington, DC.

Natana, J.D., 2009. The Freedoms Saudi Women Really Want: This article in Middle East Institute, (2016). The Kingdom of Saudi Arabia, 1979-2009: Evolution of a Pivotal State: Viewpoints Special Edition. Washington, DC.

Rashti, G., 2004. Women and education in postrevolutionary Iran: Unsettling policies and unanticipated outcomes. Proceedings of the International Political Science Association Congress. Canada.

Safaa, F.R., 2014. Women in Saudi: Status, rights and limitations. University of Washington Bothell School of Interdisciplinary Arts and Sciences, Washington.

Sanja, K., 2009. Recent Gains and new opportunities for women`s rights in the Gulf Arab States,

Smith-Spark, L., B. Anderson and S. Sarah, 2017. Saudi women celebrate news they will finally be allowed to drive. CNN.

UN, 2004. Kingdom of Saudi Arabia public administration country profile. No. 4236, Umm AlQura, 2009-01-16.

Wikipedia, 2016. Human rights in Saudi Arabia.

Yahya, A., 2015. Review of Women and Society in Saudi Arabia: The Sunday Times. 